\title{
Effect of protein level in diet and feeding schedule on the digestive enzymatic activity of Macrobrachium tenellum juveniles
}

\author{
Daniel Espinosa-Chaurand ${ }^{1}$, Olimpia Carrillo-Farnés ${ }^{2}$ \\ Fernando Vega-Villasante ${ }^{3}$ \& Héctor Nolasco-Soria ${ }^{4}$ \\ ${ }^{1}$ CONACYT - Unidad Nayarit del Centro de Investigaciones Biológicas del Noroeste \\ Tepic, Nayarit, México \\ ${ }^{2}$ Facultad de Biología, Universidad de La Habana, La Habana, Cuba \\ ${ }^{3}$ Laboratorio de Calidad de Agua y Acuicultura Experimental, Centro Universitario de la Costa \\ Universidad de Guadalajara, Puerto Vallarta, Jalisco, México \\ ${ }^{4}$ Centro de Investigaciones Biológicas del Noroeste S.C., La Paz, B.C.S., México \\ Corresponding author: Héctor Nolasco-Soria (hnolasco04@cibnor.mx)
}

\begin{abstract}
This study assessed the effect of protein level in diet and feeding schedule on the digestive enzymatic activity of Macrobrachium tenellum juveniles. Freshwater prawn juveniles $(0.31 \pm 0.004 \mathrm{~g}$ and 32.48 $\pm 0.27 \mathrm{~mm}$ ) were fed diets with $20,25,30,35$ and $40 \%$ crude protein $(\mathrm{CP})(\mathrm{p} / \mathrm{p})$. In a second experiment, feeding schedules were assessed at 08:00, 14:00 and 20:00 $\mathrm{h}$ with feed at $30 \% \mathrm{CP}$ with juveniles of $0.22 \pm 0.002 \mathrm{~g}$ and $29.36 \pm 0.28 \mathrm{~mm}$. In both experiments, five organisms were sampled after 60 days of treatment in a time-lapse of one hour (08:00 to 09:00 h) per experimental tank and treatment. The enzymatic extract was obtained from the complete organisms to determine specific general protease, trypsin, chymotrypsin, amylase and lipase activities. Greater general protease, trypsin and lipase activities were observed in feed at $40 \% \mathrm{CP}$. The feeding schedules with greater general protease, trypsin, lipase and amylase activities were found at 14:00 and 20:00 h. Chymotrypsin did not show differences among treatments at CP levels or feeding schedules. Protein level in diets for $M$. tenellum modified basal digestive enzymatic activity and increased proteolytic and lipolytic activities, while it decreased amylolytic activity as the inclusion of $\mathrm{CP}$ level increased in the diet; likewise, the activity was modified by feeding schedule, showing a direct correlation between the increase in digestive enzymatic activity and food offering at the end of the day.
\end{abstract}

Keywords: Macrobrachium tenellum; prawn; feeding schedule; digestive enzymes; digestive physiology

\section{INTRODUCTION}

Among the most important commercial Macrobrachium species, the one that stands out in the Mexican Pacific coasts is the fresh-water prawn M. tenellum (PoncePalafox et al., 2002; Espinosa-Chaurand et al., 2011). Given its high aquaculture potential (Vega-Villasante et al., 2015), its tolerance to environmental conditions as well as to its low aggressiveness toward its congeners, and its high density in the environment (Ponce-Palafox et al., 2002). Currently, cultivation techniques for its farming are in the developmental stage based on the knowledge that has been generated on the species through biological, ecological, physiological and nutritional research. Within the last ones, both the type of food and feeding strategy should be considered as they represent factors of vital importance in providing the necessary energy for its adequate growth and development, which is reflected in the growth in farmed animals (Jayachandran, 2001). In the successful cultivation of prawn, management and feeding are the most important factors because food constitutes from 40 to $60 \%$ of the production costs (Vega-Villasante et al., 2011, 2014), and protein is the most essential and expensive ingredient (FernándezGiménez, 2013).

The previous information shows the great importance of studying the physiological digestive process because it modulates consumption and better use of food; specifically, the digestive enzymatic activi-

Corresponding editor: Jesús Ponce-Palafox 
ty is responsible for crucial activity in the digestive processes (Molina et al., 2000). The digestive enzymes in crustaceans can hydrolyze a great variety of essential substrates as nutrients that are regulated by factors, such as life stage, molt cycle, body size (CadenaLlomitoa, 2000; Brito et al., 2001; Guzmán et al., 2001), protein source and level in the diet, feeding amount and frequency, and the circadian cycle (Molina et al., 2000).

In several crustacean species, the effect of food quality (different protein sources, biofloc use, food supplements or additives) (Perera et al., 2012; Xu \& Pan, 2012; Anand et al., 2013; Fernández-Giménez, 2013; Gallardo et al., 2013) and feeding frequency (Casillas-Hernández et al., 2006; Carrillo-Farnés et al., 2007; Avenido \& Serrano, 2012; Sacristán et al., 2013) on digestive enzymatic activity have been studied. Particularly, the protein level in the diet has been mentioned to affect the digestive enzymatic activity in crustaceans, increasing or decreasing the presence of enzyme units in the hepatopancreas (Lee \& Lawrence, 1985; Chen \& Lin, 1989; Sridhar et al., 1995; Galindo et al., 2002). Likewise, Casillas-Hernández et al. (2006) confirmed synchrony between shrimp feeding activity and enzymatic variation, which could be exploited to improve the production parameters by adjusting feeding schedules according to enzymatic variation.

Therefore, this research aimed to assess the effects of protein levels in the diets and feeding schedule on the digestive enzymatic activity of $M$. tenellum juveniles, contributing to the knowledge on its digestive biology and physiology and for aquaculture management improvement.

\section{MATERIALS AND METHODS}

\section{Organisms, experimental conditions, and sampling}

The fresh-water prawn Macrobrachium tenellum juveniles were collected in a natural affluent zone of Puerto Vallarta, Jalisco, Mexico (20 42'19'N, $105^{\circ} 13^{\prime} 16^{\prime \prime} \mathrm{W} ; 10$ m.a.s.l.) and transferred to the Experimental Aquaculture Laboratory of Centro Universitario de la Costa, Universidad de Guadalajara. The prawns were acclimated to laboratory conditions and made up a stock until further use.

Two 60-day independent bioassays were performed to assess the response of $M$. tenellum to protein levels in the diet and feeding schedules, particularly on digestive enzymatic activity. The first one consisted on feeding $M$. tenellum juveniles with five experimental diets $(20,25,30,35$ and $40 \%$ CP; Table 1) using 225 prawns randomly distributed (initial weight and size of
$0.31 \pm 0.004 \mathrm{~g}$ and $32.48 \pm 0.27 \mathrm{~mm}$, respectively) in 15 experimental $70-\mathrm{L}$ tanks (15 ind per tank), and fed once a day $(14: 00 \mathrm{~h})$. In the second bioassay, $135 \mathrm{M}$. tenellum juveniles (weight $0.22 \pm 0.002 \mathrm{~g}$ and size $29.36 \pm 0.28 \mathrm{~mm})$ distributed randomly in nine experimental 70-L tanks (15 ind per tanks) were fed a diet with $30 \% \mathrm{CP}$ (Table 1), and the treatments corresponded to three different feeding schedules, 08:00, 14:00 and 20:00 h. In both experiments, treatments were assessed in triplicate, and the experimental tanks were maintained with clear water by cascade filters and under controlled oxygen conditions $(5.00 \pm$ $\left.0.26 \mathrm{mg} \mathrm{L}^{-1}\right)$, temperature $\left(28.0 \pm 1.5^{\circ} \mathrm{C}\right), \mathrm{pH}(7.8 \pm 0.4)$ and photoperiod (12 h light: $12 \mathrm{~h}$ darkness); prawn feeding was once a day with $10 \%$ of live weight to assure satiation.

Once the 60-day bioassay (at day 60) concluded, five individuals in the intermolt stage were randomly sampled in a time-lapse of one hour (08:00 to 09:00 h) per experimental tank and treatment. Sample taking in each case was carried out after the juveniles fasted and rested for $24 \mathrm{~h}$. The sampled individuals were sacrificed with cold water at $4^{\circ} \mathrm{C}$, and then frozen at $-20^{\circ} \mathrm{C}$ for storage until biochemical analysis at the Northwest Biological Research Center, Comparative Physiology Laboratory, La Paz, BCS, Mexico.

\section{Analysis of digestive enzymatic activity}

Whole organisms were rinsed with distilled water, dried with absorbent paper and integrated to a homogenized pool with cold distilled water in a proportion 1:3, using a tissue homogenizer (Potter PRO $250^{\circledR}$; Pro Scientific. Oxford, CT, USA). The resulting macerated tissue was clarified by double centrifugation $(15,000 \mathrm{~g} ; \varnothing$ rotor $9.5 \mathrm{~cm})$ at $4^{\circ} \mathrm{C}$ for $10 \mathrm{~min}$, eliminating the lipid fraction, which was extracted by absorption with a micropipette for its disposal when it was found as supernatant. The clarified was recovered and preserved at $-20^{\circ} \mathrm{C}$, considered as enzyme extract (EE) to which soluble protein and amylase, lipase, general protease, trypsin and chymotrypsin were determined by triplicate.

The micro-method Bradford (1976) was used to determine the amount of protein in enzyme extract using bovine albumin serum as standard. General protease activity was determined according to VegaVillasante et al. (1995) and modified as follows: mixing $20 \mu \mathrm{L}$ of EE, $230 \mu \mathrm{L}$ of buffer Tris- $\mathrm{HCl}(50 \mathrm{mM}, \mathrm{pH}$ 8 ) and starting the reaction adding $500 \mu \mathrm{L}$ of azocasein $(0.5 \%$ in Tris- $\mathrm{HCl} 50 \mathrm{mM}, \mathrm{pH} 8)$ as substrate. The mixture was incubated in a water bath at $37^{\circ} \mathrm{C}$ for 60 min. The reaction was stopped with $500 \mu \mathrm{L}$ TCA $20 \%$, and the mixture was clarified by centrifugation $(15,000$ $\left.\mathrm{g}, 25^{\circ} \mathrm{C}, 5 \mathrm{~min}\right)$. Absorbance was measured at $440 \mathrm{~nm}$. 
Table 1. Ingredients and proximal composition of experimental feed (g per $100 \mathrm{~g}$ of dry weight). ${ }^{\mathrm{a}} \mathrm{g}$ per $200 \mathrm{~g}$ mineral premix: $\mathrm{KCl}, 28.57 ; \mathrm{MgSO}_{4} .7 \mathrm{H}_{2} \mathrm{O}, 28.57 ; \mathrm{ZnSO}_{4} .7 \mathrm{H}_{2} \mathrm{O}, 5.14 ; \mathrm{MnCl}_{2} .4 \mathrm{H}_{2} \mathrm{O}, 1.34 ; \mathrm{CuSO}_{4} .5 \mathrm{H}_{2} \mathrm{O}, 0.29 ; \mathrm{Kl}, 0.29$; $\mathrm{CoCl}_{2} .2 \mathrm{H}_{2} \mathrm{O}, 0.14 ; \mathrm{Na}_{2} \mathrm{HPO}_{4}, 135.43$, ${ }^{b} \mathrm{~g}$ per $900 \mathrm{~g}$ vitamin premix: vitamin A acetate, 100,000 UI; vitamin $\mathrm{D}_{3}, 850 \mathrm{UI}$; dialpha-tocopheryl acetate 2,000 UI; menadione, 2; thiamine- $\mathrm{HCl}, 0.5$; rivoflavin $\left(\mathrm{B}_{2}\right), 3$; pyridoxine $\mathrm{HCl}\left(\mathrm{B}_{6}\right), 1$; DL-Capantothenate, 5; nicotinic acid, 5; biotin, 0.05; inositol, 5; Vitamin $\mathrm{B}_{12}, 0.002$; folic acid, 0.18. *Proximate analysis of tested diet. Analytical method: ${ }^{\mathrm{c}}$ AOAC, 2012 (micro-Kjendahl method), ${ }^{\mathrm{d}}$ AOAC, 2012 (Soxhlet method), ${ }^{\mathrm{e}} \mathrm{AOAC}, 2012$ (Weende method), ${ }^{\mathrm{f}} \mathrm{AOAC}, 2012$ (oven at $\left.550^{\circ} \mathrm{C}\right),{ }^{\mathrm{g}}$ nitrogen free extract $=100-(\%$ crude protein $+\%$ total lipids $+\%$ crude fiber + $\%$ ashes).

\begin{tabular}{|c|c|c|c|c|c|}
\hline & \multicolumn{5}{|c|}{ Protein level } \\
\hline & $20 \%$ & $25 \%$ & $30 \%$ & $35 \%$ & $40 \%$ \\
\hline \multicolumn{6}{|c|}{ Inclusion of ingredients by experimental feed (g per $100 \mathrm{~g}$ ) } \\
\hline Whole wheat flour & 38.00 & 38.00 & 38.00 & 38.00 & 35.09 \\
\hline Corn starch & 27.18 & 19.82 & 12.47 & 5.11 & 0.00 \\
\hline Soy pasta & 10.00 & 10.00 & 10.00 & 10.00 & 10.00 \\
\hline Fish meal & 9.11 & 16.82 & 24.58 & 32.31 & 40.67 \\
\hline Cod liver oil & 5.71 & 5.33 & 4.96 & 4.58 & 4.24 \\
\hline Squid meal & 5.00 & 5.00 & 5.00 & 5.00 & 5.00 \\
\hline Mineral crustacean premix ${ }^{\mathrm{a}}$ & 2.50 & 2.50 & 2.50 & 2.50 & 2.50 \\
\hline Calcium carbonate & 1.00 & 1.00 & 1.00 & 1.00 & 1.00 \\
\hline Soy lecithin & 1.00 & 1.00 & 1.00 & 1.00 & 1.00 \\
\hline Vitamin crustacean premix & 0.30 & 0.30 & 0.30 & 0.30 & 0.30 \\
\hline Vitamin C & 0.10 & 0.10 & 0.10 & 0.10 & 0.10 \\
\hline Choline chloride & 0.10 & 0.10 & 0.10 & 0.10 & 0.10 \\
\hline \multicolumn{6}{|c|}{ Proximal composition in dry weight* ( $\mathrm{g}$ per $100 \mathrm{~g}$ in dry weight) } \\
\hline Crude protein ${ }^{\mathrm{c}}(\mathrm{N} \times 6.25)$ & $20.79 \pm 0.27$ & $26.41 \pm 0.04$ & $32.01 \pm 0.16$ & $37.63 \pm 0.19$ & $42.55 \pm 0.23$ \\
\hline Total lipids $^{\mathrm{d}}$ & $7.89 \pm 0.12$ & $7.86 \pm 0.13$ & $8.15 \pm 0.07$ & $7.99 \pm 0.04$ & $8.47 \pm 0.10$ \\
\hline Crude fiber ${ }^{\mathrm{e}}$ & $0.67 \pm 0.06$ & $0.43 \pm 0.03$ & $0.47 \pm 0.05$ & $0.36 \pm 0.06$ & $0.34 \pm 0.06$ \\
\hline$A s h^{f}$ & $6.55 \pm 0.04$ & $7.84 \pm 0.05$ & $9.04 \pm 0.02$ & $10.52 \pm 0.02$ & $11.73 \pm 0.01$ \\
\hline Nitrogen-free extract ${ }^{g}$ & 64.11 & 57.46 & 50.32 & 43.50 & 36.91 \\
\hline Energy $\left(\mathrm{kcal} \mathrm{g}^{-1}\right)$ & $4.36 \pm 0.03$ & $4.42 \pm 0.01$ & $4.55 \pm 0.02$ & $4.42 \pm 0.03$ & $4.34 \pm 0.03$ \\
\hline
\end{tabular}

The control was prepared similarly, but the EE was added after the TCA solution. The general protease activity was expressed as the number of protease units per $\mathrm{mg}$ of soluble protein. One protease unit was defined as the amount of enzyme required for increasing 0.01 absorbance units at $440 \mathrm{~nm}$ per minute.

The chymotrypsin activity was determined according to Asgeirsson \& Bjamason (1991): $10 \mu \mathrm{L}$ of EE, $890 \mu \mathrm{L}$ of Buffer (Tris $44.4 \mathrm{mM}, \mathrm{CaCl}_{2} 5.5 \mathrm{mM}, \mathrm{pH} 8$ ) were mixed, and the reaction started with $100 \mu \mathrm{L}$ de BTEE ( $5 \mathrm{mM}$ in DMSO) as substrate. The mixture was incubated at room temperature $\left(25^{\circ} \mathrm{C}\right)$ for $10 \mathrm{~min}$. The reaction stopped by boiling it for $15 \mathrm{~min}$. Once the reaction mixture cooled down $\left(25^{\circ} \mathrm{C}\right)$, absorbance was read at $256 \mathrm{~nm}$. The control was prepared similarly with denaturalized enzyme extract. The chymotrypsin activity was expressed as the number of units of chymotrypsin per mg of soluble protein. One unit of chymotrypsin was defined as the amount of enzyme required for increasing 0.01 absorbance units at $410 \mathrm{~nm}$ per minute.
The trypsin activity was determined by mixing 20 $\mu \mathrm{L}$ of $\mathrm{EE}$ and $1,250 \mu \mathrm{L}$ of substrate solution $(100 \mathrm{mM}$ of Na-Benzoyl-DL- Arginine- $\mathrm{p}$-Nitroanilide in $1 \mathrm{~mL}$ of DMSO, graduated at $100 \mathrm{~mL}$ with buffer Tris- $\mathrm{HCl}$ $50 \mathrm{mM}, \mathrm{CaCl}_{2} 10 \mathrm{mM}, \mathrm{pH}$ 8.2). The mixture was incubated at room temperature $\left(25^{\circ} \mathrm{C}\right)$ for $10 \mathrm{~min}$, and $250 \mu \mathrm{L}$ of acetic acid at $30 \%$ to stop the reaction, was added. Absorbance was read at $410 \mathrm{~nm}$; the control was prepared similarly with EE denatured (5 min in boiling water bath). Trypsin activity was expressed as the number of trypsin units per mg of soluble protein. One trypsin unit was defined as the amount of enzyme required for increasing 0.01 absorbance units at $410 \mathrm{~nm}$ per minute.

Amylase activity was determined by the method of Vega-Villasante et al. (1993): $500 \mu \mathrm{L}$ of buffer Tris$\mathrm{HCl}(50 \mathrm{mM}, \mathrm{pH} 8), 5 \mu \mathrm{L}$ of EE were mixed, and the reaction started with $500 \mu \mathrm{L}$ of soluble starch $(1 \%$ in Tris- $\mathrm{HCl}, 50 \mathrm{mM}, \mathrm{pH} \mathrm{8}$ ) as substrate. The mixture was incubated at room temperature $\left(25^{\circ} \mathrm{C}\right)$ for $10 \mathrm{~min}$, and $200 \mu \mathrm{L}$ of sodium carbonate $(2 \mathrm{~N})$ and $1,500 \mu \mathrm{L}$ of dinitrosalycilic acid (DNS) reagent to stop the reaction, 
were added. The mixture was placed in a water bath to boil for $15 \mathrm{~min}$; then, volume was adjusted at $10 \mathrm{~mL}$ with distilled water, and absorbance was read at 550 $\mathrm{nm}$. The control was prepared similarly, but EE was added after the DNS reagent. The amylase activity was expressed as the number of units of amylase per $\mathrm{mg}$ of soluble protein. One amylase unit is defined as the amount of enzyme required for increasing 0.01 absorbance units at $550 \mathrm{~nm}$ per minute.

The lipase activity was determined by the method of Nolasco et al. (2018): The incubation mixture $(200 \mu \mathrm{L}$ total volume) of the micro method procedure was as follows: $10 \mu \mathrm{L}$ sodium taurocholate (NaTau) $(100 \mathrm{mM})$ emulsifier reagent in a 96-well microplate, plus $50 \mu \mathrm{L}$ Tris- $\mathrm{HCl}$ buffer $(200 \mathrm{mM})$ and $10 \mu \mathrm{L}$ lipase extract (LE) (it can be diluted 1:10) were added. Then, to start the reaction $10 \mu \mathrm{L}$ BNC $(20 \mathrm{mM})$, substrate reagent was added. The microplate was agitated by " 8 " movements on the table, and incubate for nine minutes at room temperature $\left(25^{\circ} \mathrm{C}\right)$. After incubation, the color reaction was produced by the addition of $10 \mu \mathrm{L}$ FBBB $(20 \mathrm{mM})$ color developer, followed by an additional 1-min incubation, to get a $10 \mathrm{~min}$ total incubation. The reaction was stopped with $110 \mu \mathrm{L}$ TCA-SDS stopperclarification reagent (trichloroacetic acid (TCA) 2 and $12.5 \%$ sodium dodecyl sulfate (SDS)) and then read for absorbance at $540 \mathrm{~nm}$, after 1-min shaking at 1,500 rpm. Lipase activity was expressed as the number of lipase units per mg of soluble protein. One lipase unit is defined as the amount of enzyme required for increasing 0.01 of absorbance units at $540 \mathrm{~nm}$ per minute.

\section{Statistical analyses}

Data generated on the digestive enzymatic activity by the effect of feeding schedule and different protein levels in diet were analyzed by one-way analysis of variance (ANOVA). All the analyses were performed after the Kolmogorov-Smirnov normality $(\alpha=0.05)$ and Bartlett's homogeneity of variances $(\alpha=0.05)$ tests. Significant differences among treatments were determined by Tukey's multiple comparisons method $(\alpha=0.05)$. All the tests were performed by Sigmastat v.3.1 statistical software.

\section{RESULTS}

The enzymatic activities of the general protease, trypsin, chymotrypsin, amylase and lipase in Macrobrachium tenellum juveniles (final weight of $0.70 \pm$ $0.11 \mathrm{~g}$ and final size of $38.79 \pm 1.79 \mathrm{~mm}$ ) fed five protein levels are shown (Fig. 1). The highest digestive protease level was observed in the organisms fed with $40 \%$ of CP in the diet. A significantly higher concen- tration of trypsin was observed in the treatment with $40 \%$ of CP in the diet $(P<0.05)$ while no difference was observed in chymotrypsin among treatments $(P>$ $0.05)$. The amylolytic activity was significantly higher when organisms were fed with the diet containing $20 \%$ of $\mathrm{CP}$, a lower protein concentration used in the experimental diets, followed by one with $25 \%$ of $\mathrm{CP}(P$ $<0.05)$. Lipolytic activity was significantly higher under the treatments of 35 and $40 \%$ of CP $(P<0.05)$.

The activities of the general protease, trypsin, chymotrypsin, amylase and lipase activities of $M$. tenellum juveniles (final weight of $0.56 \pm 0.10 \mathrm{~g}$ and final size of $36.79 \pm 2.71 \mathrm{~mm}$ ) fed in different time schedules (08:00, 14:00, 20:00 h) are shown (Fig. 2). The general proteolytic activity significantly increased at 14:00 and 20:00 $\mathrm{h}$ compared to that expressed in the organisms fed at $08: 00 \mathrm{~h}(P<0.05)$ with no statistical differences between these two-time schedules $(P>$ $0.05)$. In the case of the digestive trypsin activity, the concentration was statistically more significant at 14:00 $\mathrm{h}$, followed by its activity at 20:00 $\mathrm{h}(P<0.05)$. The digestive chymotrypsin activity did not show statistical differences between the three feeding schedules assessed $(P>0.05)$. The lipolytic activity was significantly higher at 20:00 h, followed by the activity at 14:00 $\mathrm{h}(P<0.05)$. The amylolytic digestive activity was significantly higher at 14:00 and 20:00 h concerning the activity at 8:00 $\mathrm{h}(P<0.05)$.

\section{DISCUSSION}

In general, this research found an increase in the digestive enzymatic activity as the inclusion of protein level increased, which agreed with that reported by Lee et al. (1984), Le Moullac (1995), and Gamboa-Delgado (2001), who demonstrated that in Penaeus vannamei an adaptation of digestive enzymes occurred according to the organism size, protein sources and level in the diet. Naik \& Murthy (2012) indicated that the relative activity of digestive enzymes could be correlated to the nature and composition of the food consumed by the organisms. In contrast, for $P$. setiferus, Lee \& Lawrence (1985) and Lovett \& Felder (1990) mentioned that enzymatic activity varied inversely to protein level in the diet; this last behavior only agreed with that found in the amylase expression in our study.

Sagar et al. (2009) did not find a relationship between protein level and enzymatic activity of proteases, lipases and amylases in the organisms subjected to two crude protein levels (27 and 32\%) while assessing the digestive enzymatic activity of Macrobrachium rosenbergii under these two diets. This result agrees with the activity observed in our study on chymotrypsin, where independently of the protein level 

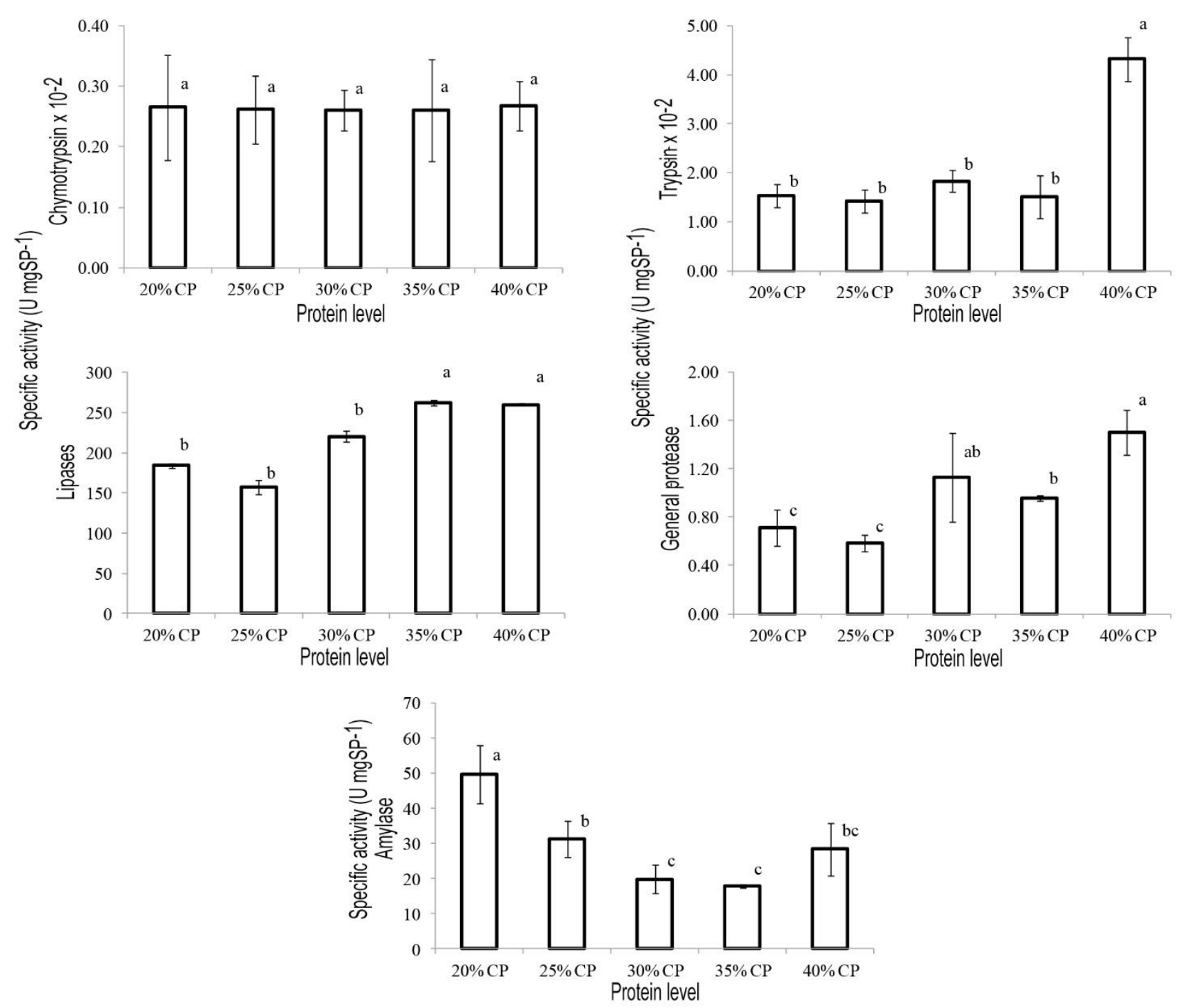

Figure 1. Comparison of general proteases, trypsin, chymotrypsin, amylases and lipases (specific activity, U mg of soluble protein $^{-1}$ ) of Macrobrachium tenellum juveniles fed five protein concentrations. Vertical lines in each bar indicate the standard deviation. Different letters on the bars indicate statistical differences $(P<0.05)$.

of the diet, a uniform concentration was maintained in M. tenellum individuals. On the other hand, Naik \& Murthy (2012) found a higher protease activity in $M$. rosenbergii with diets related to high values of essential fatty acids.

Galindo et al. (2002) reported that the highest proteolytic activities in Litopenaeus schmitti were obtained with the diets of higher protein content, which was also observed in M. tenellum juveniles in our study. On the contrary, Perera et al. (2005) did not find differences in protease levels while testing two protein levels in the diet (25 and 35\% of CP) with Panulirus argus. Besides, they mentioned that a difference was found depending on the type of ingredient used, observing that the digestive protease activity increased with the inclusion of squid flour in the diets compared to those without it.

A similar case was reported by Le Moullac et al. (1994) for the chymotrypsin activity in Penaeus (=Litopenaeus) vannamei larvae, and Perera et al. (2012) for trypsin activity in P. argus lobster, finding a higher activity of these enzymes when they added squid flour in the diets, concluding that feed type and quality influenced the digestive enzymatic activity (IsiordiaPérez et al., 2006; Naik \& Murthy, 2012). On the other hand, Sridhar et al. (1995) observed no significant differences in trypsin activity in Penaeus indicus while using the three diets at different protein levels $(30,34$ and $36 \% \mathrm{CP}$ ), which differed with our research on $M$. 

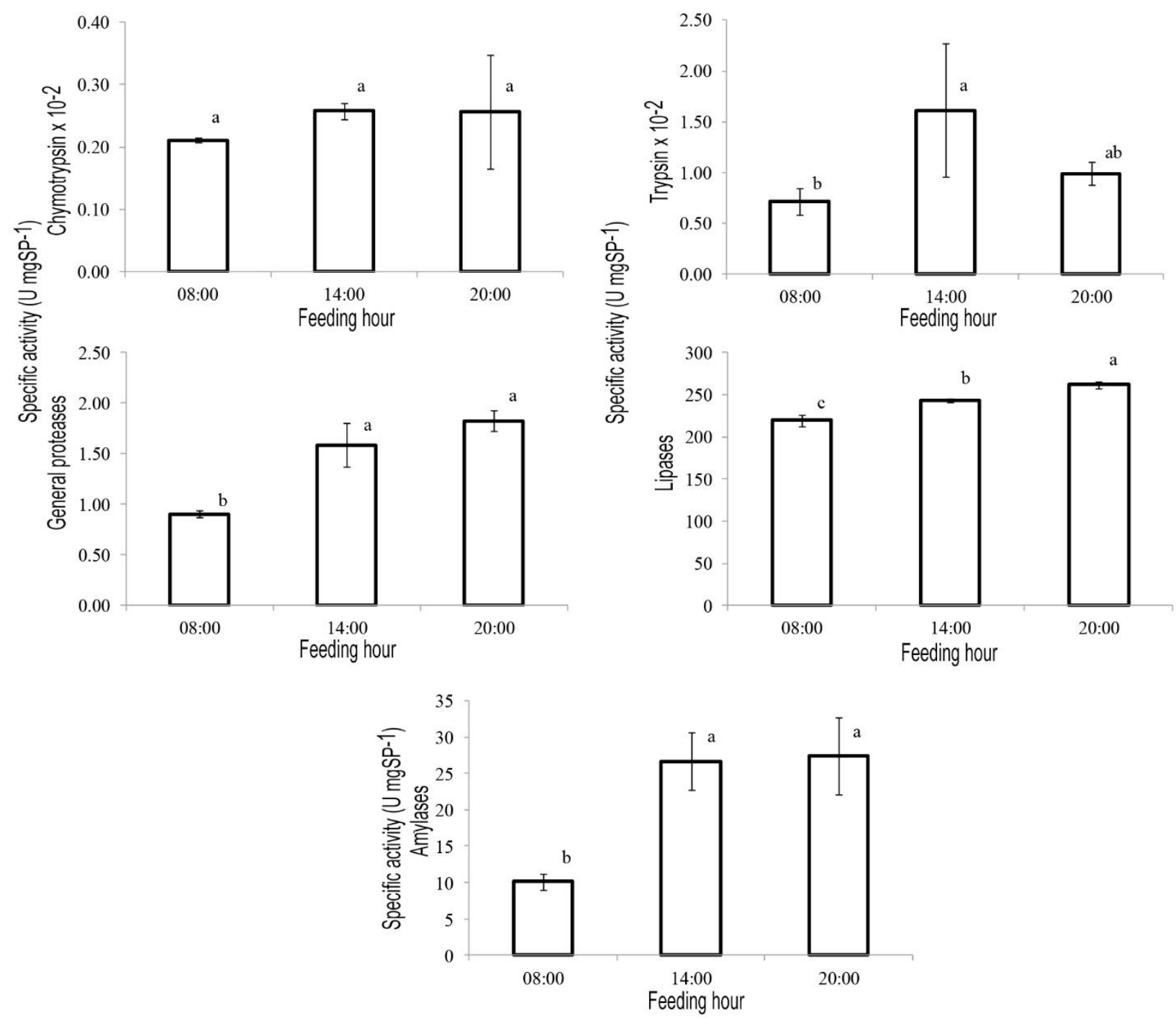

Figure 2. Comparison of general proteases, trypsin, chymotrypsin, amylases and lipases (specific activity, $\mathrm{U}$ mg protein ${ }^{-1}$ ) of Macrobrachium tenellum juveniles in feeding schedules. Vertical lines in each bar indicate the standard deviation. Different letters on the bars indicate statistical differences $(P<0.05)$.

tenellum, where a difference was found in trypsin activity while increasing protein level to $40 \%$.

In general, the digestive enzymatic behavior in $M$. tenellum was affected by the protein level in the diet, increasing proteases and lipases and decreasing amylases as the protein level of the diet increased. One cause of the inverse behavior between proteases and amylases could be related to the inclusion of different levels of other nutritive substrates in the experimental diets, while increasing protein concentration, a decrease in the level of nitrogen-free extract occurred (mainly starch provided by vegetal ingredients used in feed formulation that are generally used to adjust protein concentration in diets). Notably in this study, corn starch inclusion was reduced as protein level in diets increased, while the use of lipids could have increased to satisfy the energy demand of the organism due to the relationship mentioned between carbohydrates and proteins present in the experimental diets, it resulted in the increase of lipolytic activity as protein increased in the diets.

The hepatoprancreas is the main lipid reservoir; the composition and availability of the fatty acids present will depend on the combination between the diets offered, compound biosynthesis, and temperature (Ahmed et al., 2015). To summarize, substrate specificity is one of the valid criteria to distinguish the type of enzymes present in an organism (Forjan et al., 2000; Bornscheuer, 2002). 
Substrate hydrolysis not only depends on the digestive enzymatic capacity of the organism to convert food in useful substances for its nutrition (Cruz-Suárez et al., 2002), but also on the substrate quantity present and the feasibility of being hydrolyzed (its digestibility) besides the fact that each enzyme has a characteristic substrate concentration to be saturated (Whitaker, 1996; Nelson \& Cox, 2009).

Although, undoubtedly, the presence and activity of digestive enzymes in crustaceans are influenced by many internal and external factors (Casillas-Hernández et al., 2006; Fernández-Giménez, 2013), synchrony between feeding activity and digestive enzymatic variation could be confirmed when the digestive enzymatic activity was analyzed to see if it was affected by zootechnical management practices (CasillasHernández et al., 2006). Thus, the possibility of performing an exogenous stimulation exists through different feeding schedules despite having a biphasic circadian rhythm in the enzymatic activity (NolascoSoria \& Vega-Villasante, 2000).

By knowing the organisms' circadian rhythms of the digestive enzymatic activities, their feeding hour and frequency could be established (González et al., 1995; Nolasco et al., 1997; Nolasco-Soria \& VegaVillasante, 2000; Casillas-Hernández et al., 2006), which would avoid excessive nutrient losses by lixiviation (Cuzon et al., 1982; Casillas-Hernández et $a l ., 2006)$ and would help management programs for incorporating food to the digestive tract close to the time schedule of its maximum digestive capacity. Moreover, it would also increase hydrolysis speed and favor complete digestion of nutrients for their absorption and metabolism (Nolasco et al., 1997; Casillas-Hernández et al., 2006), and in consequence, improve organism growth (Cuzon et al., 1982; Nolasco et al., 1997; Casillas-Hernández et al., 2006), pond conditions and feeding costs (Nolasco-Soria \& VegaVillasante, 2000).

Unequal patterns have been found, in enzymatic activity peaks, when the organisms are fed at different time schedules, modifying them depending on feeding time (Díaz-Granda, 1997; Molina et al., 2000). Our research study agrees with those of Nolasco et al. (1997) on Litopenaeus californiensis, and Molina et al. (2000) on $P$. vannamei in which the behavior of general proteases, trypsin, chymotrypsin, amylases and lipases showed greater activity in the afternoon at night schedules. However, it disagreed with that mentioned by Díaz-Granda (1997) in L. schmitti for these enzymes, as a higher activity was reported in our study in the morning schedule $(10: 00 \mathrm{~h})$, indicating a daytime habit preferably for the feeding activity of this last species.
Digestive enzymes play an important role in digestion and maximum use of food (Van Wormhoudt, 1977; Rosas et al., 2001); knowing the moment at which the organisms are more capable of consuming and digesting food will have advantages for its management. For this reason, considering adjusting feeding schedules to digestive enzyme variation could result in better practices (Casillas-Hernández et al., 2006).

To conclude, the protein level in the diets of $M$. tenellum modified basal enzymatic activity, increasing proteolytic and lipolytic activities, and decreasing amylolytic activity as the inclusion of crude protein level in the diet increased. Likewise, the activity was modified as the feeding schedule changed, showing a direct relationship in the increase of the digestive enzymatic activity with food offering at the end of the day $(08: 00 \mathrm{~h}<14: 00 \mathrm{~h}<20: 00 \mathrm{~h})$. To our knowledge, these results have been reported for the first time in $M$. tenellum, which will allow establishing management techniques and nutritional considerations at the moment of formulating a diet for the species. Moreover, they provide information to understand better the digestive physiology of these organisms and their application to establish better feeding schedules.

\section{ACKNOWLEDGMENTS}

The authors thank Centro de Investigaciones Biológicas del Noroeste S.C. (CIBNOR) Comparative Physiology Laboratory, especially Patricia Baltazar Hinojosa for technical support, the staff of the experimental Aquaculture Laboratory of Guadalajara University (UdeG), and to Diana Fischer for editorial services.

\section{REFERENCES}

Ahmed, P., Sudan, M. \& Sikdar, M. 2015. Effect of photoperiod and temperature on development and growth of hepatopancreas of freshwater prawn Macrobrachium dayanum. International Journal of Fisheries and Aquatic Studies, 3(1): 173-178.

Anand, P.S.S., Kohli, M.P.S., Roy, S.D., Sundaray, J.K., Kumar, S., Sinha, A., Pailan, G.H. \& Sukham, M.K. 2013. Effect of dietary supplementation of periphyton on growth performance and digestive enzyme activities in Penaeus monodon. Aquaculture, 392-395: 59-68.

Asgeirsson, B. \& Bjarnason, J.B. 1991. Structural and kinetic properties of chymotrypsin from Atlantic cod (Gadus morhua). Comparison with bovine chymo- 
trypsin. Comparative Biochemistry and Physiology B, 99: 327-335.

Avenido, P. \& Serrano, A.E. 2012. Twig extract of the apple mangrove affects the activities of trypsin, chymotrypsin, and lipase in postlarval black tiger shrimp Penaeus monodon at varying feeding frequencies. ELBA Bioflux, 4(2): 56-61.

Bornscheuer, U.T. 2002. Microbial carboxyl esterases: classification, proprieties, and application in biocatalysis. FEMS Microbiology Reviews, 26: 73-81.

Bradford, M.M. 1976. A rapid and sensitive method for the quantification of microgram quantities of protein utilizing the principle of protein-dye binding. Analytical Biochemistry, 72: 248-254.

Brito, R., Rosas, C., Chimal, M.E. \& Gaxiola, G. 2001. Effect of different diets on growth and digestive enzyme activity in Litopenaeus vannamei (Boone, 1931) early post-larvae. Aquaculture Research, 32: 257-266.

Cadena-Llomitoa, E. 2000. Relación entre el ciclo de muda y la actividad de las enzimas digestivas y su efecto en la tasa de alimentación y el crecimiento del juvenil Penaeus vannamei. Tesis de Grado, Escuela Superior Politécnica del Litoral, Guayaquil.

Carrillo-Farnés, O., Forrellat-Barrios, A., GuerreroGalván, S. \& Vega-Villasante, F. 2007. A review of digestive enzyme activity in penaeid shrimp. Crustaceana, 80(3): 257-275.

Casillas-Hernández, R., Nolasco-Soria, H., Lares-Villa, F., García-Galeano, T., Carrillo-Farnés, O. \& VegaVillasante, F. 2006. Ritmo circadiano de la actividad enzimática digestiva del camarón blanco Litopenaeus vannamei y su efecto en el horario de alimentación. Revista Latinoamericana de Recursos Naturales, 2(2): 55-64.

Chen, H.Y. \& Lin, H.F. 1989. The effects of exogenous enzymes on the growth of early postlarval Penaeus monodon. In: Hiran, R. \& Hanyu, I. (Eds.). Proceedings of the Second Asian Fisheries Forum. Tokyo, Japan, pp. 349-352.

Cruz-Suárez, E. 2002. Digestión en camarón y su relación con formulación y fabricación de alimentos balanceados. In: Cruz-Suárez, L.E., Ricque-Marie, D., Tapia-Salazar, M., Gaxiola-Cortés, M.G. \& Simoes, N. (Eds.). Avances en nutrición acuícola VI. Memorias del VI Simposio Internacional de Nutrición Acuícola. Cancún, Quintana Roo, pp. 207-232.

Cuzon, G., Hew, M., Cognie, D. \& Soletchnik, P. 1982. Time lag effect of feeding on growth of juvenile shrimp Penaeus japonicus Bate. Aquaculture, 29: 3344.
Díaz-Granda, A.E. 1997. Horarios de alimentación del camarón Penaeus schmitti en condiciones de cultivo semi-intensivo. Tesis de Magister, Centro de Investigaciones Marinas, Universidad de la Habana, La Habana, 120 pp.

Espinosa-Chaurand, L.D., Vargas-Ceballos, M., GuzmánArroyo, M., Nolasco-Soria, H., Carrillo-Farnés, O., Chong-Carrillo, O. \& Vega-Villasante, F. 2011. Biología y cultivo de Macrobrachium tenellum: estado del arte. Hidrobiológica, 21(2): 99-117.

Fernández-Giménez, A.V. 2013. Digestive physiology of three species of decapod crustaceans of Argentina. Journal of Shellfish Research, 32(3): 767-777.

Forjan, P., Jonson, P.H., Petersen, M.T.N. \& Petersen, S.B. 2000. What distinguishes an esterase from a lipase: a novel structural approach. Biochimie, 82: 1033-1041.

Galindo, J., Fraga, I., de Arazoza, M., Álvarez, J.S., Ramos, D. \& González, R. 2002. Requerimientos nutricionales de juveniles de camarón blanco (Litopenaeus schmitti): evaluación de dietas prácticas. I Congreso Iberoamericano Virtual de Acuicultura, pp. 84-94.

Gallardo, P., Martínez, G., Palomino, G., Paredes, A., Gaxiola, G., Cuzon, G. \& Pedroza-Islas, R. 2013. Micro-encapsulated diets: effect on development, digestive enzymes and body composition of white shrimp, Litopenaeus vannamei, larvae. Journal of the World Aquaculture Society, 44(2): 187-197.

Gamboa-Delgado, J. 2001. Estudio de la actividad de las enzimas digestivas de Litopenaeus vannamei en función del tamaño corporal y la preferencia alimenticia. Tesis de Magister, Escuela Superior Politécnica del Litoral, Guayaquil, 49 pp.

González, R., Gómez, M. \& Carrillo, O. 1995. Variaciones cronobiológicas de la actividad de las principales enzimas proteolíticas de Penaeus schmitti y Penaeus notialis. Revista de Investigaciones Marinas, 16(1-3): 177-183.

Guzmán, C., Gaxiola, G., Rosa, C. \& Torre-Blanco, A. 2001. The effect of dietary protein and total energy content on digestive enzyme activities, growth, and survival of Litopenaeus setiferus (Linnaeus, 1767) postlarvae. Aquaculture Nutrition, 7: 113-122.

Isiordia-Pérez, E., Puello-Cruz, A., D’Abramo, L. \& González-Vega, H. 2006. Evaluación de la actividad enzimática y contenido de proteína en larvas de camarón blanco Litopenaeus vannamei alimentadas con diferentes dietas. Revista Electrónica de Veterinaria, 3(4): 1-13.

Jayachandran, K.V. 2001. Palaemonid prawns: biodiversity, taxonomy, biology, and management. Science Publishers, New Hampshire. 
Le Moullac, G. 1995. Adaptation des enzymes digestives a l' alimentation chez la crevette Penaeus vannamei (Crustacea, Decapoda). In: D'Abramo, L.R., Conklin, D.E. \& Akiyama, D.M. (Eds.). Crustacean nutrition. Advances in world aquaculture. World Aquaculture Society, Baton Rouge.

Le Moullac, G., Van Wormhoudt, A. \& Aquacop. 1994. Adaptation of digestive enzymes to dietary protein, carbohydrate and fiber levels, and influence of protein and carbohydrate quality in Penaeus vannamei larvae (Crustacea, Decapoda). In: D'Abramo, L.R., Conkiln, D.E. \& Akiyama, D.M. (Eds.). Crustacean nutrition. Advances in world aquaculture. World Aquaculture Nutrition, Baton Rouge.

Lee, P.G. \& Lawrence, A.L. 1985. Effects of diet and size on growth, feed digestibility, and digestive enzyme activities of the marine shrimp Penaeus setiferus (Linnaeus). Journal of the World Mariculture Society, 16: 257-287.

Lee, P.G., Smith, L.L. \& Lawrence, A.L. 1984. Digestive proteases of Penaeus vannamei (Boone): relationship between enzyme activity, size, and diet. Aquaculture, 42: 225-239.

Lovett, D.L. \& Felder, D.L. 1990. Ontogenic change in digestive enzyme activity of larval and postlarval white shrimp Penaeus setiferus (Crustacea, Decapoda, Penaeidae). Biological Bulletin, 178: 144-159.

Molina, C., Cadena, E. \& Orellana, F. 2000. Alimentación de camarones en relación a la actividad enzimática como una respuesta natural al ritmo circadiano y ciclo de muda. In: Cruz-Suárez, L.E., Ricque-Marie, D., Tapia-Salazar, M., Olvera-Novoa, M.A. \& CiveraCerecedo, R. (Eds.). Avances en nutrición acuícola. Memorias del V Simposium Internacional de Nutrición Acuícola, Mérida, pp. 358-379.

Naik, A.T.R. \& Murthy, H.S. 2012. Effect of dietary administration of sardine oil on growth, survival, and enzymatic activity of Macrobrachium rosenbergii (de Man). Israeli Journal of Aquaculture - Bamidgeh, 64: 1-6.

Nelson, D.L. \& Cox, M.M. 2009. Principios de bioquímica. Omega, Barcelona.

Nolasco, H., Tovar-Ramírez, D., Flores-Bravo, M.A., García-Aboites, C., Vega-Villasante, F., Oliva, M. \& Fernández, I. 1997. Digestive enzymatic activity of shrimp and its relation with the circadian rhythm and bacterial flora. La bioquímica en la biotecnología marina. Universidad de la Habana, La Habana.

Nolasco-Soria, H. \& Vega-Villasante, F. 2000. Actividad enzimática digestiva, ritmos circadianos y su relación con la alimentación del camarón. In: Civera-Cevedo, R., Pérez-Estrada, C.J., Ricque-Marie, D. \& CruzSuárez, L.E. (Eds.). Avances en nutrición acuícola. Memorias del IV Simposio Internacional de Nutrición Acuícola, La Paz, B.C.S., pp. 149-165.
Perera, E., I. Fraga, O. Carrillo, E. Díaz-Iglesias, R. Cruz, M. Báez \& G.S. Galich. 2005. Evaluation of practical diets for Caribbean spiny lobster Panulirus argus (Latreille, 1804): effects of protein source on substrate metabolism and digestive proteases. Aquaculture, 244: 251-262.

Perera, E., Rodríguez-Viera, L., Rodríguez-Casariego, J., Fraga, I., Carrillo, O., Martínez-Rodríguez, G. \& Mancera, J.M. 2012. Dietary protein quality differential regulates trypsin enzymes at the secretion and transcription level in Panulirus argus by distinct signaling pathways. Journal of Experimental Biology, 215: 853-862.

Ponce-Palafox, J.T., Arana-Magallón, F.C., CabanillasBeltrán, H. \& Esparza, H. 2002. Bases biológicas y técnicas para el cultivo de los camarones de agua dulce nativos del Pacífico americano Macrobrachium tenellum (Smith, 1871) y M. americanum (Bate, 1968). I Congreso Iberoamericano Virtual de Acuicultura, pp. 534-546.

Rosas, C., Cuzon, G., Gaxiola, G., Le Priol, Y., Pascual, C., Rossignol, J., Contreras, F., Sánchez, A. \& Van Wormhoudt, A. 2001. Metabolism and growth of juveniles of Litopenaeus vannamei: effect of salinity and dietary carbohydrate levels. Journal of Experimental Marine Biology and Ecology, 259: 1-22.

Sacristán, H.J., Franco-Tadic, L.M. \& López-Greco, L.S. 2013. Influence of feeding on the circadian rhythm of digestive enzymes in cultivated juveniles of the freshwater crayfish Cherax quadricarinatus (Parastacidae). Latin American Journal of Aquatic Research, 41(4): 753-761.

Sagar, V., Sahu, N.P., Pal, A.K., Jain, K.K. \& Venugopal, G. 2009. Growth and digestive enzymes of Macrobrachium rosenbergii juveniles: effect of different stock types and dietary protein levels under a similar culture environment. Aquaculture Research, 40: 1383-1393.

SigmaStat. 2004. SigmaStat. Advisory Statistics for Scientists. SYSTAT software Inc.

Sridhar, M., Nair, R.J. \& Sridhar, N. 1995. Trypsin activity as a function of variation in shrimp Penaeus indicus (Crustacea/Arthropoda). Indian of Journal Marine Science, 24: 110-112.

Van Wormhoudt, A. 1977. Activités, enzimatiques digestives chez Palemon serratus variations annuelles de l'acrophase des rythmes circadiens. Biochemical Systematics and Ecology, 5: 301-307.

Vega-Villasante, F., Nolasco, H. \& Civera, R. 1993. The digestive enzymes of the Pacific brown shrimp Penaeus californiensis - I. Properties of amylase activity in the digestive tract. Comparative Biochemistry and Physiology B, 106: 547-550. 
Vega-Villasante, F., Nolasco, H. \& Civera, R. 1995. The digestive enzymes of the Pacific brown shrimp Penaeus californiensis - II. Properties of protease activity in the whole digestive tract. Comparative Biochemistry and Physiology B, 112: 123-129.

Vega-Villasante, F., Martínez-Ochoa, E.F., GarcíaGuerrero, M.U. \& Arrona-Ortiz, J.D. 2015. Efecto de diferentes intensidades de luz sobre la expresión de cromatóforos, crecimiento y supervivencia en juveniles de Macrobrachium tenellum. Latin American Journal Aquatic Research, 43(1): 255-261.

Vega-Villasante, F., Espinosa-Chaurand, L.D., YamasakiGranados, S., Cortés-Jacinto, E., García-Guerrero, M.U., Cupul-Magaña, A.L., Nolasco-Soria, H. \& Guzmán-Arroyo, M. 2011. Acuicultura del langostino Macrobrachium tenellum: engorda en estanques semirrústicos. Universidad de Guadalajara, Jalisco, 88 pp.

Received: 15 January 2019; Accepted: 17 May 2019
Vega-Villasante, F., García-Guerrero, M.U., CortésJacinto, E., Yamasaki-Granados, E., MontoyaMartínez, C.M., Vargas-Ceballos, M.A., ChongCarrillo, O., Rubio-Padilla, M.A., Guzmán-Arroyo, M., Carrillo-Farnés, O.V., Espinosa-Chaurand, L.D. \& Nolasco-Soria, H.G. 2014. Los camarones de agua dulce del género Macrobrachium: biología, ecología y explotación. In: Cifuentes-Lemus, J.L. \& CupulMagaña, F.G. (Eds.). Temas sobre investigaciones costeras. Universidad de Guadalajara, Jalisco, pp. 273315.

Whitaker, J.R. 1996. Enzymes. In: Fenneman, O.R. (Ed.). Food chemistry. Mercel Dekker, New York, pp. 431529.

Xu, W-J. \& Pan, L-Q. 2012. Effects of bioflocs on growth performance, digestive enzyme activity, and body composition of juvenile Litopenaeus vannamei in zero-water exchange tanks manipulating $\mathrm{C} / \mathrm{N}$ ratio in feed. Aquaculture, 356-357: 147-152. 